\title{
CORRIGENDUM
}

\section{From metaphors to measures: observable indicators of gradual institutional change - CORRIGENDUM}

PHILIP ROCCO AND CHLOE THURSTON

doi:10.1017/S0143814X13000305, Published online by Cambridge University Press, 16 December 2013.

On the $16^{\text {th }}$ page of the article, an error appeared within the quote from Thelen, which should read, "away from the decentralized artisanal system toward the centralization, standardization and uniformity that are now considered its core and defining features", rather than "not" to describe the German training model.

\section{Reference}

Rocco P. and Thurston C. From Metaphors to Measures: Observable Indicators of Gradual Institutional Change. Journal of Public Policy, first published online 16 December 2013, doi:10.1017/S0143814X13000305. 